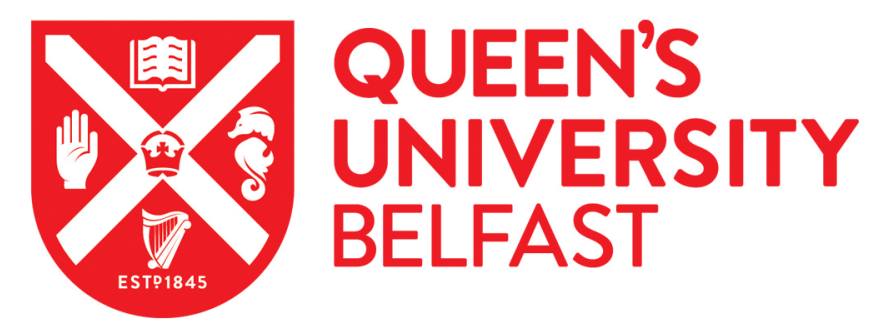

\title{
Medical students need experience not just competence
}

Dornan, T., Gillespie, H., Armour, D., Reid, H., \& Bennett, D. (2020). Medical students need experience not just competence. The BMJ, 371, [m4298]. https://doi.org/10.1136/bmj.m4298

\section{Published in:}

The BMJ

\section{Document Version:}

Peer reviewed version

Queen's University Belfast - Research Portal:

Link to publication record in Queen's University Belfast Research Portal

\section{Publisher rights}

Copyright 2020 the authors.

This work is made available online in accordance with the publisher's policies. Please refer to any applicable terms of use of the publisher.

\section{General rights}

Copyright for the publications made accessible via the Queen's University Belfast Research Portal is retained by the author(s) and / or other copyright owners and it is a condition of accessing these publications that users recognise and abide by the legal requirements associated with these rights.

Take down policy

The Research Portal is Queen's institutional repository that provides access to Queen's research output. Every effort has been made to ensure that content in the Research Portal does not infringe any person's rights, or applicable UK laws. If you discover content in the Research Portal that you believe breaches copyright or violates any law, please contact openaccess@qub.ac.uk. 
Competence does not guarantee capability. The need for medical students to have sufficient clinical experience

Tim Dornan ${ }^{1}$, Hannah Gillespie², Dakota Armour ${ }^{3}$, Helen Reid ${ }^{4}$, Deirdre Bennett ${ }^{5}$

${ }^{1}$ Professor of Medical Education, ${ }^{2} \mathrm{PhD}$ Student, ${ }^{3}$ Medical student, ${ }^{4} \mathrm{Clinical}$ lecturer

Centre for Medical Education

Queens University Belfast

Whitla Medical Building

97 Lisburn Road

Belfast BT9 7BL

UK

${ }^{5}$ Head, Medical Education Unit

School of Medicine

Brookfield Health Sciences Complex

University College Cork

Cork

Ireland

Corresponding author: t.dornan@qub.ac.uk 
Anticipating a serious workforce shortage, the World Health Organisation advocates a paradigm shift in how we prepare clinicians for practice. (1) This editorial is a critical review of medical student education, which supports that recommendation. Curricula vary internationally: students are health workers in some countries and observers in others; they progress from medical school to hospital generalist training in some countries and direct to specialties in others. We acknowledge that variability so far as a limited evidence-base dominated by anglophone publications allows.

Britain is the main source of evidence about preparedness for practice. This may be because UK students, with little experience of contributing to practice, shoulder heavy clinical responsibilities as foundation trainees (FTs). Despite this inexperience, FTs' supervision may be 'arms-length' when, for example, a hospital specialist delegates patients' generalist care to them. This baptism of fire may explain why an increasing proportion of UK trainees deviate from the intended training pathway. Two thirds of FTs delay entry to specialties, some taking career breaks out of medicine.(2) The staffing gaps that result make patient care discontinuous, impersonal, and potentially unsafe, and incur eye-watering locum costs. Paradoxically, UK trainees break their training to become better trained. Taking a break from training relieves them from work pressures, unsupportive learning environments, unsatisfactory education, disrupted personal lives, and poor psychological health. Some, also, want longer to choose a specialty.(3)

These factors, though, are an insufficient explanation for the UK's retention problem. Only $10 \%$ of trainees (interns and residents) in the US, Netherlands, and New Zealand take career breaks (4-6) despite negative psychosocial experiences. $(7,8)$ The relative immaturity of UK trainees cannot explain their career breaks because students enter medicine direct from high school in the Netherlands and New Zealand too. Trainees leave when a final negative experience 'brings down the tower of blocks'.(9) Negative experiences start in medical school (3) and intensify when students become trainees.(10) Trainees with the least developed coping strategies are worst affected.(11) Those in the UK certainly need coping strategies because the National Health Service, whilst affording excellent training opportunities, operates under formidable pressure. Promises of ever 'safer' healthcare whilst ever less is spent on public services have resulted in expertise being so thin on the ground that work is often shared out rather than supervised. Students need to be very well prepared for work.

The competency movement has strongly influenced global reforms in medical education.(12) This new paradigm has shifted the arbiter of being ready for work from having accrued sufficient experience to having demonstrated competence, off-the job, in standardised tests. By that objective definition, 100\% of UK students are ready to practise 'safely', yet practice is not demonstrably safer. The General Medical Council's survey of UK graduates' experiences of starting work shows that a progressively falling proportion (66\% in 2019, compared with $90 \%$ or more in the US) find themselves, subjectively, prepared. $(13,14)$ Subjective unpreparedness might be dismissed as 'soft evidence' but this predicts dissatisfaction with training, poor wellbeing, and burnout for up to seven years after qualification.(13)

The stressors that test medical graduates' preparedness include feeling incapable of managing a heavy workload against the clock, on unfamiliar wards, on call, and lonely; facing criticism and conflict; and managing very sick patients who deteriorate despite treatment. Trainees who have only learned parttasks (eg writing a simulated prescription) find themselves incapable of performing the whole task (treating a sick patient). Unpreparedness is 'knowing what' but not 'knowing how'. It is having such a fragile professional identity that you cannot admit uncertainty.(15-17) Competent but incapable graduates are sitting ducks for psychosocial harm. 
There is observational evidence that students can be better prepared by gaining experience in real practice contexts, not just simulation; having longer, better supported experiential attachments; having a placement in a hospital where they will soon work; having generalist rather than specialist experience; and not having constant exam pressures.(18) Narrative evidence suggests that North American students, despite also being in competence-based programmes, have more such experience than UK students. The importance of ensuring that students have had enough experience applies to any job, be it hairdressing, coal-mining, or healthcare. Students become capable trainees by immersing themselves in work, observing and listening, role-modelling, interacting with workers, participating in work practices, being coached, asking and answering questions, reading workplace documents, and writing in them.(19)

This cautionary tale leads us to propose that medical education does not so much need a paradigm change as a stronger implementation of the World Federation for Medical Education's paradigmatic standards. These advocate early, progressively increasing involvement in patient care and experience of taking responsibility.(20) Off-the-job training, observing practice, and a relentless diet of assessments cannot substitute for experience. On the job learning, alone, can actualise students' and trainees' intrinsic motivation to care well for patients.

Word count: 791 words

66

Competing interests statement

We have read and understood the BMJ Group policy on declaration of interests and have none to declare

\section{Contributions}

Tim Dornan wrote the editorial and headed the team of authors. Hannah Gillespie and Dakota Armour searched information sources to provide the evidence-base for it. Helen Reid and Deirdre Bennett contributed to the drafting and revision of the editorial. All authors approved all drafts, including the final submitted version.

\section{License}

The Corresponding Author has the right to grant on behalf of all authors and does grant on behalf of all authors, a worldwide licence to the Publishers and its licensees in perpetuity, in all forms, formats and media (whether known now or created in the future), to i) publish, reproduce, distribute, display and store the Contribution, ii) translate the Contribution into other languages, create adaptations, reprints, include within collections and create summaries, extracts and/or, abstracts of the Contribution, iii) create any other derivative work(s) based on the Contribution, iv) to exploit all subsidiary rights in the Contribution, v) the inclusion of electronic links from the Contribution to third party material where-ever it may be located; and, vi) licence any third party to do any or all of the above.

Acknowledgements

87 We thank Dr Huon Snelgrove and Professor Hiroshi Nishigori for constructive criticisms of our original submission, which helped us focus and strengthen our argument. 
2. General Medical Council. 2019 F2 Career Destinations Survey. London; 2019.

95 3. General Medical Council. Training pathways 2 : why do doctors take breaks from their training?

5. Medical Council of New Zealand. The New Zealand Medical Workforce in 2018.

101

102

103

6. Lu DW, Hartman ND, Druck J, Mitzman J, Strout TD. Why residents quit: National rates of and reasons for attrition among emergency medicine physicians in training. West J Emerg Med. 2019;20(2):351-6.

7. van Vendeloo SN, Prins DJ, Verheyen CCPM, Prins JT, van den Heijkant F, van der Heijden FMMA, et al. The learning environment and resident burnout: a national study. Perspect Med Educ. 2018;7(2):120-5.

8. Pereira-Lima K, Gupta RR, Guille C, Sen S. Residency Program Factors Associated with Depressive Symptoms in Internal Medicine Interns: A Prospective Cohort Study. Acad Med. 2019;94:869-75.

9. Liang R, Dornan T, Nestel D. Why do women leave surgical training? A qualitative and feminist study. Lancet. 2019;393(10171):541-9.

10. Mata DA, Ramos MA, Bansal N, Khan R, Guille C, Di Angelantonio E, et al. Prevalence of depression and depressive symptoms among resident physicians a systematic review and meta-analysis. JAMA - J Am Med Assoc. 2015;314(22):2373-83.

11. Teunissen $\mathrm{P}$, Westerman M. Opportunity or threat; ambiguity in the consequences of transitions in medical education. Med Educ. 2011;45:51-9.

12. Cooke M, Irby DM, O'Brien BC. Educating Physicians: A Call for Reform of Medical School and Residency. Carnegie Foundation for the Advancement of Teaching. San Francisco: Jossey-Bass; 2010.

13. General Medical Council. Progression Reports: Foundation Year 1 Pereparedness. London;

14. Association of American Medical Colleges: Medical School Graduation Questionnaire 2019 All Schools Summary Report [Internet]. 2019. Available from: https://www.aamc.org/download/498790/data/2019gqallschoolssummaryreport.pdf

15. Illing JC, Morrow GM, Rothwell nee Kergon CR, Burford BC, Baldauf BK, Davies CL, et al. Perceptions of UK medical graduates' preparedness for practice: a multi-centre qualitative study reflecting the importance of learning on the job. BMC Med Educ. 2013;13:34.

16. Monrouxe L, Bullock A, Cole J, Gormley G. How Prepared are UK Medical Graduates for Practice? Final report from a programme of research commissioned by the General Medical Council [Internet]. 2014. Available from: http://www.gmcuk.org/How_Prepared_are_UK_Medical_Graduates_for_Practice_SUBMITTED_Revised_140614.p df_58034815.pdf

17. Lee C, McCrory R, Tully M., Carrington A, Donnelly R, Dornan T. Readiness to prescribe: using educational design to untie the Gordian Knot. PLoS One [Internet]. 2020; Available from: https://doi.org/10.1371/journal.pone.0227865

18. Medical Board of Australia and Ahpra. Medical Training Survey 2019. 2020.

19. Billett S, Choy S. Integrating Professional Learning Experiences across University and Pratice Settings. In: Billett S, Harteis C, Gruber H, editors. International Handbook of Research in Professional and Practice-based Learning. Dordrecht: Springer; 2014. p. 485-512.

20. Basic Medical Education. WFME Global Standards for Quality Improvement. 2015 Revision. 
139

Copenhagen; 2015.

140 